\title{
Self Actualization According to Bediuzaman Said Nursi (1877-1960) in Risale-I Nur
}

\author{
Abdul Gaffar ${ }^{1}$, Fitriah M. Suud ${ }^{2 *}$, Hamim Ilyas ${ }^{3}$, Ali Ridho ${ }^{4}$ \\ ${ }^{1,2}$ Universitas Muhammadiyah Yogyakarta, ${ }^{1,4}$ Institut Agama Islam Al-Khairat Pamekasan \\ ${ }^{3}$ Universitas Agama Islam Negeri Sunan Kalijaga \\ Corresponding Author:*fitriah@umy.ac.id
}

\begin{abstract}
Bediuzzaman Said Nursi is one of the thinkers and reformers from Turkey who emerged as a figure of Sufism, the savior of faith and Islam in the 19th century. This research found a formulation of the self-actualization process that was different from the concepts of other scientists. According to Said Nursi, humans' self-concept consists of several natures: the rabbani nature, the nafsani nature, the spiritual nature, the physical nature, the tafakkur nature, and the tadhabbur nature. Some of these natures depend on the characteristics of the human soul journey, which cannot be separated from the fulfillment of worldly and spiritual needs and the ultimate need in the form of spirituality. Said Nursi's self-actualization positions as one of the alternative thinking frameworks based on the Koran, which goes through a four-step self-actualization process: through devotion to Allah by burying arrogance (abdun wa al-faqr), through the light of faith in God, through manifesting Asma-ul-Husna (Names of Allah) reflected in oneself, and by following the path of the Qur'an as the path of nature. Even Said Nursi repeatedly emphasized that every human being actually has the potential in the form of intrinsic faculties residing in his heart, soul, and intellect. Those popularly known as Al-Tafakkur, Tadhabbur, Al-'Ajz, Al-Fāqr, and Al-Shäfaqah are called spiritual innovations that lead to the development of tauhid to shape character and behavior towards perfect humans (Inshan Al-Kamil).
\end{abstract}

Keywords

Self Actualization, Bediuzaman Said Nursi, Risale-I Nur, Islamic Psychology, Turkey

\section{Introduction}

Psychology is a scientific discipline considered by some as an entity of scientific representatives, which is empirically factual. It can only be approached with an objective approach that cannot deny science development, especially neuropsychology. It has been so dominated by modern civilization, which is more oriented towards secular (western) science understandings (Wahyuna et al., 2020) as the trigger for the dichotomy between scientific activities and the area of religious spirituality. Thus, this dominance makes psychology work in the empirical area by denying non-empirical (mystical) areas.

The majority of almost all psychological studies are mainstream, especially in the theory of personality and human needs; under normal conditions, each individual is still dominated by the need for the id, ego, and superego. Franze Alexander has tried to connect the id, ego, and superego to neurosis and psychosis. It was built on Sigmund Freud's opinion to arrive at a very significant neurosis conclusion, describing the conflict between the ego and the id (instinctive need); psychosis between ego and the outside world; and narcissistic neurosis as a struggle between ego and superego. However, Frued has not been able to answer in the realm of conscience in terms of spirit religion (inner needs), which has been discussed in the theory of self-actualization (Alexander, 1935:67).

In the Qur'an, it is mentioned that $n \bar{a} f s$ has the connotation of "self", while in psychology, the entity is identified as ego; ego is equivalent to $n \bar{a} f s$. It is stated in the Qur'an that another dimension of the self includes what is called nafsul lawwamah. This structure is identified as the superego, which Sigmund Frued has categorized. The Qur'an also expresses another structure of the soul, namely the nafsul mutmainnah, which no psychologist except Abraham Maslow and Kurt Goldstein disclosed. Besides, nafsul mutmainnah due to the pressure of nafsul lawwamah is based on $n \bar{a} f s$, which is oriented towards prayer and worship. Meanwhile, 
calmness and peace are dominant and dangerous drives, and Satan does not affect those (Nursi, 2003c:19)

Humans' inner capacity potential can develop themselves (self-actualization) to reach the socalled superman or ubermensh, which in Islam known as insan al-kamil. The inner capacity potential is part of the indication of Allah's existence and can never be fully actualized without any spiritual relationship with God. Said Nursi explained that there are two sides in human beings: leading to the pseudo-world life from the side of egoism and leading to eternal life from the side of devotion.

According to Said Nursi, the foremost goal of Allah's creation is the greatest original disposition (fitrah) in the form of faith in Allah. The highest level of human nature (basyariah) is makrifatullah, all of which are embedded in faith. Likewise, the most beautiful pleasure and happiness (Masyhuri et al., 2020) for every human being and the jinn are mahabbatullah (love of Allah), which arises because of makrifatullah. Said Nursi added that the clearest joy of the human soul in the heart's joy is a spiritual delicacy, which is imprinted because of the mahabbatullah (Nursi, 2017a:382).

The body will always interact with the spirit if humans are a form of creation that can be understood through physical and psychological movements. The inner capacity (spirit) is limited by the form of the physical "prison parts". If the spirit can control $n \bar{a} f s u$ through faith, worship, and good deeds and free itself from the bondage of worldly desires, then this inner capacity becomes pure and attains holiness and glory.

Said Nursi's position emerged as a reformer in the construction of "saving faith and Islam". He has a character of thought in favor of faith, understanding of the Al-Quran, the Last Day, and scientific integrality. Besides, he was also a brave and persistent figure in fighting for Muslims in Turkey at the end of the Ottoman Empire, which sparked the idea of defending religion and socialsocial life, preventing humans from falling into an atmosphere of destruction in free culture (Ihsan Kasim Salih, 2003:v).

Said Nursi is more inclined towards cultural resistance; through his writings and lectures, he moved people to the faith civilization. Said Nursi has consistently fought against secularization in Turkey until he has produced a work "Risālah Al$N \bar{u} r^{\prime \prime}$, 6000-page writing containing thoughts on building a civilization of the faith essence. It was then continued by his successors, called Thullabun Al-Nur in this century, including Recep Toyyip Erdogan, who made Risālah Al-Nür part of one of his government's spirits (Ahmad Junaidi, 2016:58-140)

\section{Methodology}

This research used Poul Ricoeur's hermeneutic technique through a self-actualization approach in humanistic psychology. In the hermeneutical technique, three essential elements must be considered: the context of thought, authentic meaning (from something that is being studied), and relevance (from the original meaning with the past/original context to the meaning that is appropriate to the current and contemporary context) (Minhaji, 2009:94). There are three stages in the interpretation process, including the semantic, reflective, and existential levels.

\section{Semantic understanding stages}

Semantic understanding is the initial stage as an entrance for interpreting to existential understanding in the area of linguistic studies (Ricoeur,1970:35). The interpreter is required to be a bridge between the object and the subject to carry out an understanding. According to Ricoeur's hermeneutics, the process of interpretation begins with guesswork (Ricoeur, 1970:37). It means guessing the meaning in a text related to a language form, then the meaning of the text is no longer the same as the author's meaning and intent. In Bediuzzaman Said Nursi's work, a text full of metaphorical language, the writer should guess the meaning of the text considering that the author is no longer present to accompany the Risālah Al-Nür text. The writer departed from language analysis on the analysis of 
semantic structures on human expressions with various meanings in a higher direction.

\section{Reflective understanding stages}

The reflective stage is a bridge between the semantic and existential stages because language actually deals with the existential (Ricoeur, 2005:27). This stage is a process that connects understanding the text and understanding oneself (Ricoeur, 2005:30). This reflection stage is related to the expression of life, which processes from indirect awareness through work to express the actus being human. In the context of Said Nursi's thought, the writer attempted to reveal selfactualization in Risālah Al-Nūr through interpretation.

\section{Existential understanding stages}

This stage is the interpretation of being. Ricoeur's existential stage goes through a symbol, a semantic, and a reflective stage (Ricoeur, 1996:56). Data collection, both empirical (primary) in the form of Risālah Al-Nūr and those from literature (secondary) with self-actualization themes, was carried out before conducting the research. It was done so that the writer could understand the self-actualization concept in Said Nursi's thoughts through the Risālah Al-Nūr Book. This initial data collection was certainly beneficial in enriching the writer's ideas when conducting research that sought to find his works (Saifuddin, 2005:29). In some of his works, Said Nursi's ideas are crucial because they are very decisive for the formulation or discovery of theories, although the relationship between ideas and theories in library research itself is still debated among scientists (Ricoeur, 1996:27; Suud et al., 2020).

\section{Results}

\section{The concept of "self" in humans, according to Said Nursi}

Bediuzzaman Said Nursi appreciates the human "self" with many potentials (both dhohir and inner potential). The writer found this self-concept in formulation into several forms, including:

\section{Rabbani Nature}

In humans, there is always an influence on the soul's movement of surrender to God and His creation and human tendencies in matters of a theological nature; nature of reason works to integrate sincerity in life to serve. This world can be recognized, and humans can know it. Allah has given abilities to humans. The divine call on humans to know the horizons and their souls attests to humans' ability to know various aspects of life. Said Nursi said:

".... The instant life enters it, and it establishes such a connection with the universe that it is as though it concludes a trading agreement with it, especially with the flowers and plants of the earth. It can say: "The earth is my garden; it is my trading house." Thus, through the unconscious, instinctive senses which impel and stimulate it in addition to the well-known five external senses and inner senses of animate beings, the bee has a feeling for, and a familiarity and re- reciprocal relationship with, most of the species in the world, and they are at its disposal" (Nursi, 2008:532).

Humans are equipped with five senses to develop all potentials, so that knowledge, strength, sight, hearing, and possession are part of the manifestation of Divine light. Said Nursi places it as a mirror for God's names written to humans (as the names of God are seen in our comprehensive nature) (Nursi, 2003a:301). As was initially designed, the purpose of human creation is not just to eat, drink, joke, and play and then die and become dirt. Likewise, humans are not created to accumulate material possessions and leisure, simply like animals.

\section{Spiritual nature}

In the design of the spirit and body creation, both have their level. Allah SWT places the spirit as the highest creation, while the body is placed at the lowest level. The movement of the human body is not the soul but the nature of matter itself. It was mentioned earlier that there is the highest soul in humans, namely alnathiqat (thinking creature). It is called the "spiritual" essence, manifested in the understanding of Allah's names. The soul 
(ruhani) in the language of the Qur'an is called al-ruh, which is breathed by Allah SWT when the fetus has been in the womb for four months. It is when the body of a human fetus has grown and developed because of its material nature before Allah's breathed al-ruh:

"Spirit is also a conscious and living law which has come from the World of the Divine Command, and which Pre-Eternal power has clothed with external existence. That is to say, just as the unconscious laws which proceed from the Divine attribute of will and the World of the Divine Command are always, or mostly, enduring, so it is even more definite that the spirit, which is a sort of brother to them, and like them is a manifestation of the attribute of will and comes from the World of the Command, manifests immortality. It is also more worthy of it because it is existents; it has an external reality. Moreover, it is more potent, more elevated because it possesses consciousness. It is also more enduring than them, and more valuable because it is living" (Nursi, 2008:537).

The spirit is imprinted in conscience that does not forget the slightest bit of Allah SWT even though wild reason tries to get rid of, not to care for, and deny His existence. Conscience keeps making it by seeing Allah SWT while contemplating and facing Him. Meanwhile, his intuition moved him, inspiration always illuminated him, and divine love continued to drive him to know his Creator (Nursi, 2014b:507).

\section{Tadhabbur Nature}

Tadhabbur, as stated by Said Nursi, is to practice all the sunnah of the Prophet Muhammad and carry out all the commands of Allah SWT in accordance with the instructions in the Qur'ān that are fardhu 'ain, such as performing prayers by completing the terms and conditions, followed by reading zikir, as exemplified by the Prophet Muhammad (al-ma'tsurat) and leaving major sins (al-kabair).

“.....the understanding and imaginative power of one person the scope of whose comprehension is very narrow concerning time, place, and specialization, cannot truly expound the Qur'an, for he cannot be acquainted with and be an expert in all the exact sciences and the branches of knowledge concerned with the spiritual and material states of nations and peoples, all of whom the Qur'an addresses" (Nursi, 2013:14).

The tadhabbur path is likened to a freeway that is easily traversed. It does not require the assumption of the belief that beings do not exist at all, as believed by the wahdat al-wujud group of people. They say: "No maujud except Allah SWT". This tabhabbur is solely shown to achieve serenity in worship and attain awareness of the heart (al-hudhur al-qalbi). Likewise, for the Wahdat al-syuhud adherents, they set aside creatures to the realm of nisyan (forgetfulness/unconsciousness).

"So long as it is not corrupted in any way, human nature confirms it. For an easy conscience and peace of mind are to be found through its lights. That is to say, unspoiled human nature affirms it through the testimony of a tranquil conscience and says to the Qur'an through the tongue of disposition: "Our natures cannot be perfected without you!" We have proved this truth in many places".(Nursi, 2014c:227).

Through the medium of tadhabbur as the principle of the path of guardianship and as the behavior basis, the world must be recognized as a field for good deeds, not a place to reap the rewards and get rewards. It is proven that the peak of tadhabbur that Said Nursi often uses

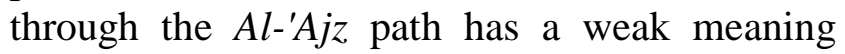
attributed to Allah's servant. This characteristic is imprinted in the form of a very short and safe bridge because it will lead to eternal truth in the form of beloved $\dot{Z} a t$, none other than the media way of worship by totality to Allah. This kind of nature is described as al-isyq (longing) by reflecting the nature of Al-Qadir the Khaliq (Nursi, 2014c:230).

\section{Physical Nature}

A human being will always be influenced by the 
movement of the soul, which has a human tendency to achieve a holy soul condition in the sight of Allah and increasing performance by worship to obtain something, which, of course, appears to be in harmony with piety. If humans meet the natural needs of the body, it will tend to activate courageous natures, which will gradually be cultivated and formed into the characteristics of a piety soul. Said Nursi said:

"As far as physical diseases are concerned, we may seek refuge from them when they hinder our worship. However, we should seek refuge in a humble and supplicating fashion, not protesting and plaintively. If we accept God as our Lord and Sustainer, then we must accept too all that He gives us in His capacity of Sustainer. To sigh and complain in a manner implying objection to Divine Determining and Decree is a kind of criticism of Divine Determining, an accusation leveled against God's compassion. The one who criticizes Divine Determining strikes his head against the anvil and breaks it" (Nursi, 2000:26-27).

Physically, humans consist of several devices, including the senses, inner feelings, and nature. It is based on nothing but two pillars: 1) so that within oneself, there is a sense of gratitude for every kind of blessing that Allah gives; in other words, humans must attend, give thanks, and worship Him and 2) so that the human self knows the various forms of Asmaul Husna manifestation, which cover all of nature and enjoy them one by one (Nursi, 2014a:164).

\section{Tafakkur Nature}

The nature of reason or thinking is called al-aql, according to Al-Kindi, as translated by T. J. De Boer, divided into four parts (Boer., 1903:327). They are 1. Active intellect, namely a mind that is always acting. 2. Intellect potential is the mind potentially in the human soul. 3. Intellect that passes from potential reason to actual reason is the mind that has changed in the "soul" from nature to actual. 4. Intellect is born with knowledge without being put into practice.

Specifically, Said Nursi explained that the ego is divided into two parts, which is undoubtedly different from the ego concept expressed by Sigmund Freud. For Nursi, the ego is tafakkur, the key to unlocking the hidden treasures of Allah's names and the locked secrets of nature, which have two sides. The first is the literal (harfi) thinking side. This thinking model leads to the nature of prophethood (Sultoni et al., 2020) to become a place for the growth of sincere servitude (ubudiyah) to Allah.

"Tafakkur is knowing himself as a servant of Allah and obeying his God. He understands that his substance has a literal meaning, which shows a meaning other than Him. He believes that his form is only an accessory. It stands with an existence other than itself and with its creation. He knows that his ownership of something is only an assumption. It means that it is temporary and physical in accordance with the permission of the true owner. The essence is only a shadow, not genuine. It means that it is possible, creation, small, and has a weak image, reflecting the manifestation of the essence of wajibul wujud (compulsory form). Thus, what was done by the prophets, the apostles, and among the noble people (the guardians) saw the ego through recognizing the attributes of Allah" (Nursi, 2016:13).

The second is the side of Ismi's thinking, which is thinking which has become a tool of philosophy as a source of truth. Ego tafakkur ismi shows meaning to himself through himself (Nursi, 2016:14). Its meaning and existence reside in himself and work for himself, while his form is considered authentic and original, not a shadow. $\mathrm{He}$ is considered to have a special character. $\mathrm{He}$ feels that he has rights in life and is an intrinsic owner in his territory by considering his assumptions as real essence (Nursi, 2016:16).

"Man's superiority over other living beings and his high rank is in respect to his elevated qualities, comprehensive abilities, universal worship, and his extensive spheres of existence. However, the virtues he acquires like zeal, love, brotherhood, and humanity are to the extent of the fleeting present, which 
is squeezed between the past and the future, which are both non-existent, and dead, and black" (Nursi, 2003c:244).

\section{Nafsani Nature}

The existence of lust that exists in humans will continue to influence the movement of the soul and the tendency of humans to do social things and tend to work hard greedily to get something. Humans have an infinite essence and have the potential and ability to be right or wrong. It is because man has been created as free will with the knowledge and wisdom considered the basis of freedom and will, setting the stage for human involvement in his destiny and assigning him the task of change (Keshavarz, 2012). As stated by Said Nursi:

“...... represented forms, whether pictorial or concrete, are either embodied tyranny, or embodied hypocrisy, or embodied lust; they excite lust and encourage man to oppression, hypocrisy, and licentiousness. Moreover, the Qur'an compassionately commands women to wear the veil of modesty so that they will be treated with respect, and those mines of compassion will not be trodden under the feet of low desires, nor be like worthless goods for the excitement of lust..." (Nursi, 2008:423).

There are countless incidents and events that greed always leads to loss and regret. As the saying goes, in general, everyone confirms that "Greedy people always fail and lose." If you love wealth, the key is labor with an attitude of qonaah without being accompanied by an attitude of greed so that it will come to you in huge numbers (Nursi, 2017a:474).

\section{Figure The concept of "self" in humans}

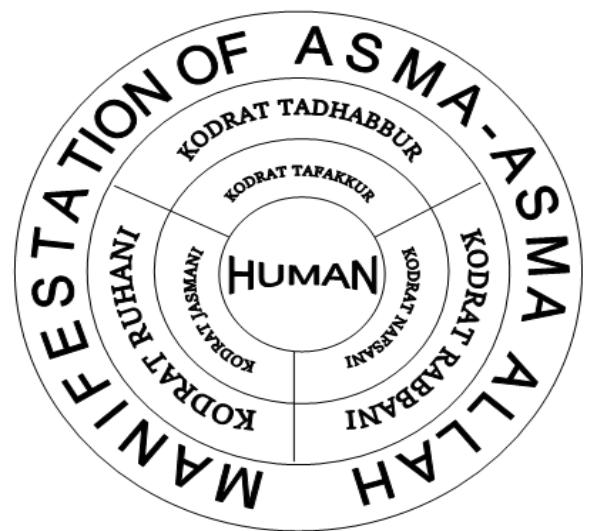

From the figure above, it can be seen that the essence of "self" in humans is the "manifestation of Allah's names", which is composed of both material and non-material natures, each of which has a relationship. For example, the nature of tafakkur is related to the nature of tadhabbur. Tafakkur is a form of work (process) of the reason that promotes rationality by placing philosophical justification as the only source of knowledge. Meanwhile, tadhabbur is the heart (spiritual) work, which places the source of the truth of empiricism (such as inspiration and revelation) as the only source of knowledge.

\section{Human needs according to Said Nursi}

Hierarchically, according to Said Nursi, human needs begin with two needs as the basic foundation of thinking: worldly needs and ukhrawi needs. Worldly needs include the needs of Nafsani, the need for a sense of qona'ah, the need for a sense of wara', and the need for a sense of brotherhood. Meanwhile, the needs of $u k h r a w i$ consist of a sense of faith and tawakkal, an attitude of tafakkur based on tauhid, a sense of ihsan and compassion, and divine love. According to Said Nursi, all of them still have something to do with the human "self" concept model, as explained above. The basic movement and thought of Said Nursi in dealing with various problems in his life always lead to a profound understanding and appreciation, namely the AlQuran and Al-Hadith. The fruit of Said Nursi's long contemplation resulted in the concept of 
"Positive Charity" or al-'amal al-ijabi (positive action), which becomes a reference for every vital value as a weapon in achieving the need for security, both in this world and the hereafter (Nursi, 2017a:56).

Ustadi Hamsah discussed Müsbet Hareket (positive action) on Said Nursi's thoughts. It was explained that there is a connection between müsbet (requiring friendly behavior) and hizmet (striving for useful and meaningful behavior). To strive for good behavior, it is not enough to act, but it is balanced with good intentions, objects, tools, and outputs from the behavior results that are also well reflected (Hamsah, 2019:272).

\section{Figure Bediuzzaman Said Nursi's Hierarchy of Human Needs}

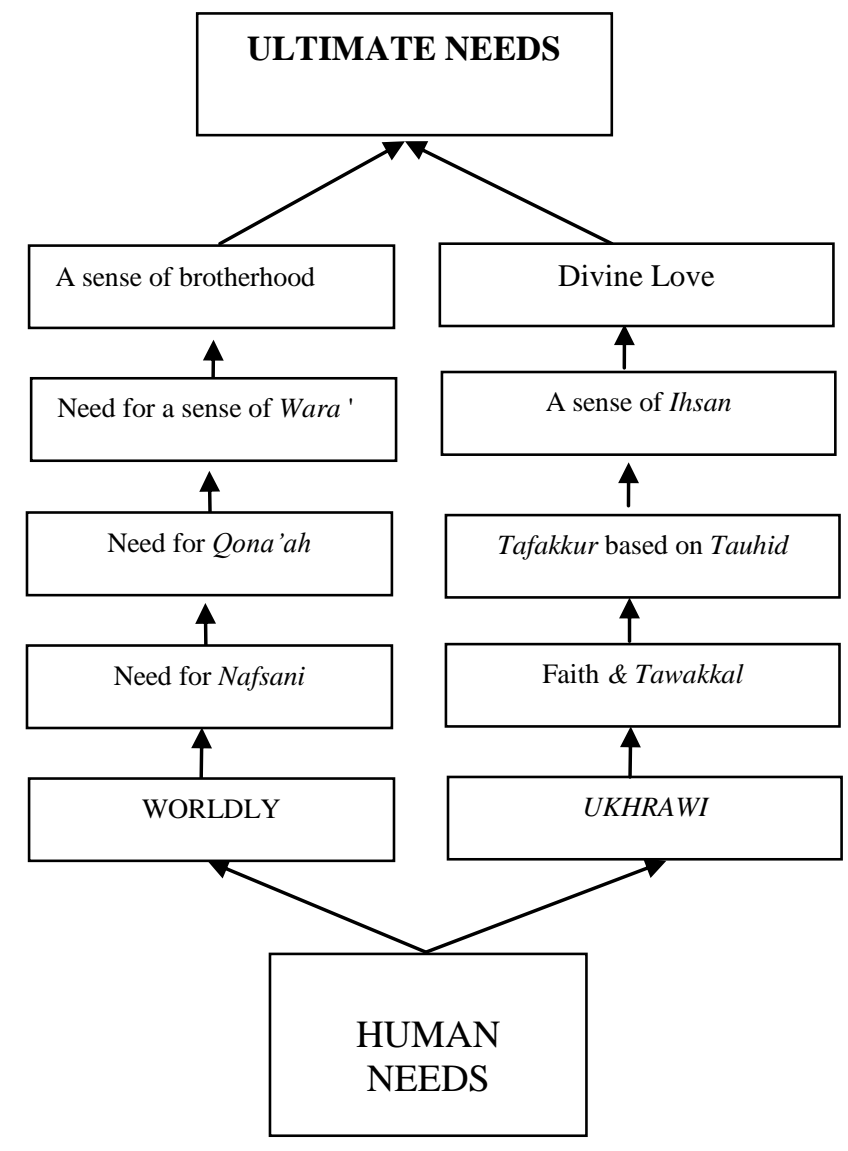

\section{Spirituality as the ultimate need}

Said Nursi explained a close relationship between the body and soul (mind), even influencing one another. When the body is afflicted with a disease, the soul is also troubled, and vice versa.
Experience in the medical field proves that often, complaints are caused by the soul; for example, irritation, disappointment, feelings of guilt, feelings of guilt, grief, hopelessness, and so on. The human soul is capable of integrating physical, psychological, and spiritual. Human life's physical aspect has been sustained by natural wisdom, vegetables, and animals for a long time; human psychic function is rooted in the individual soul (Nursi, 2017b:70). Said Nursi indicated it on "Syar'i habit", namely to decorate oneself with the number of degrees of perfection and desire that every human being deserves (Nursi, 2017a:29-30).

The peak need for Said Nursi is the purification of the soul through spiritual principles by positioning "self" as a "servant of faith", believing that the journey of the development of the human soul to seek identity is none other than the fortress of Tauhid (Nursi, 2017b:26).

"Humans whose souls are illuminated by the light of faith can convey all their needs without any hindrance in the presence of the Most Beautiful, the Greatest, the Most Powerful, the Most Perfect. They can ask for something that can fulfill their wishes wherever and whenever they are. They can reveal their desires and all their needs in front of the Most Loving, who has a vast treasure trove of grace by relying on His absolute strength. With that, they become joyous and happy" (Nursi, 2017b:66-67).

Judging from several arguments and narratives expressed by Said Nursi, spirituality is divided into two parts:

\section{The Despicable and The Lowest Spirituality}

The despicable and the lowest spirituality is the experience felt by a person with a dirty heart and filled with lust. It is more accurately called spiritual tyranny, which is the soul (nafs) that can keep people from being transcendent. At this level, the personality reaches a level that is not optimal, like reaching the lowest level (Frager, 2005:50). Said Nursi elaborates many of his arguments in work entitled "Risalah Ana \& Thabiat; Denying the Ego, Denying the Philosophy of Naturalism" (Risālah Al-Nūr collection). People who practice spiritual disgrace are dominated by the 
motivations of the needs of the nafsani, including the way of thinking.

This despicable spirituality is called a group of heretics, referred to as "adhõllîn", namely people who have slipped into naturalism and adherents of naturalist thought:

"Eight years before starting to write Risālah Al$N \bar{u} r$, I witnessed an imaginary event. It is when I was in Istanbul during the blessed month of Ramadan. At that time, "Old Said," who was busy with philosophy, had almost entered the "New Said" phase. At that time, while contemplating the three paths mentioned in the closing of the Al-Fatihah, which means: "The way of those whom you give pleasure to; it is not the way of those who are angry with and neither are those who go astray", Said Nursi witnessed the imaginary incident resembling a dream. At that time, I wrote it in Al-Lawami's work in the form of an imaginary journey and resembled Nadzham (a string of poetry). Now comes the time to elaborate and explain because it will clarify the above's essence (Nursi, 2017a:25).

\section{Praiseworthy and The Most Holy Spirituality}

According to Said Nursi, the name for someone who has a commendable spiritual experience is alladinah an'amta 'alaihim, namely that people who are on this path will find a straight and radiant path, which is intended for those who adhere to the Qur'ān. The path is the shortest, safest, easiest, and open for anyone to walk on.

“... I also continued walking, suddenly two things in my hand. The first was an electric light that illuminated the darkness underground. The second was heavy equipment that could destroy a coral as big as a mountain. The road was opened for me, and at that time, someone whispered in my ear, "this lamp and heavy equipment have been given to you from the treasures of the Qur'ān." For a while, I kept walking until I reached the other side of the mountain. Suddenly, the sun shone brightly with a beautiful clear sky that was not cloudy at all. At that time, it was a beautiful spring. The wind blew slowly, and freshwater flowed. I also saw a nature-filled with beauty and joy. Then, I did the tafakkur process. It turned out that everything I witnessed was not mine because I was unable to control it " (Nursi, 2014a:28).

\section{Self-actualization and Insan Al-Kamil Self-actualization, as the caliph of Allah}

According to Said Nursi, human interaction with nature can be concluded into more specific interactions, such as interactions between humans and God (as worshipers), interactions between humans (as humans in society), and interactions between humans and other entities (as caliph). This interaction concept is ongoing in every mukallaf and is carried out as a mandate. It is not just an ethical or alternative duty but a human duty. It is also explained in Allah's saying in Surah Al-Taha: 55 and Surah Al-Qasas: 77.

Desire motive factors that are not based on needs are very influential in damaging the universe, such as economic and political motives. In Said Nursi's term, it is trapped in the interests of the metaphorical nafsani, explained by Allah in QS Ar-Ruum verse 4: "It has appeared that the damage on land and at sea was caused by the actions of human hands so that Allah will feel for them as part of (the result) of their actions so that they return (to the right path). One of the manifestations of human-caused natural damage is the rising temperature of the earth, which influences climate change. Increasing earth temperatures significantly affect the global climate, whose conditions are increasingly uncertain. The rainy season exceeds the usual time, and the dry season feels much drier than usual. One of the efforts to prevent and control the causes of natural disasters is to promote ecotheological prophetic ethics (Salim, 2010:3).

Creating a living environment in a balanced life is very dependent on human activities; natural disasters are none other than God's punishment (Zainuddin, 2013:45-60). The spirituality crisis of modern humans in the discourse of ecological problems builds an alternative ecological imagination based on God's greatness as the source of all life and the responsibility of the human caliphate in carrying out the trust that God 
has given him (Khitam, 2016). As an ecological renewal, ecological, spiritual conceptualization is needed to answer sustainable needs by raising a spiritual awareness of nature as God's creation, which must be kept sacred through awareness in attitude and ethics (Fios, 2019).

\section{Self-actualization, as the Servant of Allah}

Said Nursi pays attention to the issue of worship intensively, especially regarding the order of faith and until now, it remains a form of fundamental commitment for him and his followers. The form of "the principle of strengthening the faith" really becomes the basis for every Muslim. In other words, faith can be understood as faith or taubid. Ismail Raji 'Al-Faruqi stated that:

"The essence of religious practice in Islam is monotheism, namely the recognition that there is no god but Allah (La illaha illa Allah). Monotheism puts humankind on an ethical act or act, namely ethics in which human worth as a moral agent is measured by the level of success achieved in filling space and time, in itself also the surrounding environment"(AlFaruqi, 1980:35).

This opinion strengthens that some life experiences are human experiences as servants of Allah, as in QS. Adz-Dzariyat: 56. God's conception is that $\mathrm{He}$ has no form, shape, or gender, nor is it an object or being. On the contrary, $\mathrm{He}$ is unique and unlike creation, as stated in the Qur'an, "there is nothing like Him" (Nursi, 2014d:675). This famous statement about the nature of Allah has dominated Islamic theology for centuries: "Whatever comes to your mind about His nature, God is different from that" (Nursi, 2014d:453). According to Said Nursi, the duties of worship and servitude to Allah ('ubudiyyah) are taught by the verse of the Qur'ān: "And I did not create jinn and humans except to worship Me", only realized by knowing Allah SWT.

Said Nursi explained that the meaning of worship is the prostration of a servant with love and admiration in the face of the perfection of rububiyah, power, and divine grace while witnessing one's shortcomings, weaknesses, and poverty. According to Said Nursi, if rububiyah's power demands ubudiyah and obedience, then His holiness also demands that a servant acknowledge the existence of his God who is clean from all deficiencies, far from the sight of heretics who are vanity, and holy from all defects of creatures. The perfect Rububiyah demands the servant be in harmony solemnly, take refuge, and trust in Him because he sees the weakness and immodesty of all creatures while saying Allahuakbar with great admiration (Nursi, 2011:43).

“... They (humans) are the writings of rabbani, subhani mirrors, and divine messengers. Thus, in addition to degrading entities from levels of divine assignment and spiritual missions, kufr's attitude also brings them down to the level of vanity and chance without value, accompanied by their condition that they will perish and leave, which then turns them into something useless. At the same time, the kufr attitude also denies Asmaul Husna, whose writing, manifestation, and beauty are clearly visible in the mirror of the whole world (Nursi, 2017b:24).

Experience of immortality (ubudiyah) tends to increase itself to the Almighty. In the context of Islamic teachings, devotion to oneself deeply by fully believing in the existence of Allah SWT is the highest goal of human creation. The purest goal of creation and the highest human nature is faith in Allah. Men are miniatures of this great realm; it is reflected in surah al-Fatihah, so prayer is nothing but a shining indicator that includes all forms of worship and a holy map that explains all models of creature worship (Nursi, 2011:44). When viewed from the aspect of religious practice, Said Nursi's offers are strengthening faith through the spirit of monotheism, entering human life down to the inner recesses.

Tauhid is the primary basis for expressing faith perfectly. Meanwhile, man's task is to obey Allah in totality because he becomes a balance to recognize his Creator's qualities and the standard for knowing his condition. The essence of faith as a whole can be understood through the pillars of 
faith. Said Nursi emphasized that belief in Allah is the most important ideal of every individual being, and the most glorious result is the belief in Allah.

As the darkness of the night shows the existence of light, all human beings through weakness, immodesty, poverty, poverty, deficiency, and all their defects indicate the existence of strength, might, wealth, glory, sufficiency, and the perfection of Allah SWT. Human individuals are not equal to each other's requirements of existence, including physical or mental strength. Each individual has been endowed with a set of natural, social, and intellectual traits that are different from the others (Rahmatullah, A.S., \& Azhar, M. 2020) God has created them who differ from the prudence of his destiny. However, each individual's responsibility level before the rigors of creation and the best of gifts is limited to the scope of his potential and strength and how he will apply that potential in life. Due to weakness, shortcoming, and immodesty, humans, through oral intrinsically, call on Allah SWT with the call of Al-Qadīr wa Al-Qahhār.

Through the language of poverty and insufficiency, humans naturally always call on Allah SWT by calling Al-Razzāq wa Al-Ghaniyy. Thus, it goes on, with all the characteristics of their deficiencies, humans always depend on Allah, who is perfect. For someone, knowing or leaving the obligation in the form of worship directly wrongs himself, remembering his position as a servant of Allah, as well as denying his status as a creature of Allah. According to Said Nursi, kufr is the greatest insult to human existence itself; likewise, neglect in worship is a denial of the perfection of creation and denial of the wisdom of divine nature (Nursi, 2014b:363).

\section{Towards Insan Al-Kamil}

Humans are the only creatures capable of manifesting Allah's name and nature, both in the form of the Majesty and Beauty of Allah. Angels cannot possibly manifest Allah's nature, who is Forgiving, Most Forgiving, and Most Recipient of Repentance because angels never sin. God cannot be called the Most Merciful, Most Forgiving, and
Most Repentant without sinful creatures and servants, while angels never sin.

Insan Kamil proposed by Said Nursi is not much different from the idea put forward by Ibn Arabi, which was then followed by Al-Jilli. According to Ibn Arabi, the perfect human being is the whole universe. Allah wants to see His substance in nature as a whole, which includes all that exists. Because this is form and to Him, He reveals His secret, the emergence of a perfect human (Insan Kamil), according to Ibn Arabi, is the essence of the natural mirrors of beauty. Ibn Arabi distinguishes perfect human beings into two, as illustrated by Dawam Raharjo. The first is a perfect human being in his position as a new human being. The second is a perfect human being in his position as an immortal. Therefore, the perfect man is new, emerging, surviving, and immortal (Raharjo, 1997:17).

According to Said Nursi, the level of human beings always feels the Creator's existence and positions itself as a being. Insan Kamil or perfect human is a quib or axis, where everything goes around from start to finish. A person's faith causes him to become a real human.

"O disciples of Nur and the servants of the Qur'an! We are all parts or organs in a meaningful figure worthy of being called "insan kamil" (perfect human being). We are all in the position of the factory gear and wheels knitting eternal happiness in eternal life. We are servants working in a "rabbani boat", which carries Muhammad's people to the shore of salvation; Dârussalâm (place of peace). If so, we desperately need unity, cooperation, and the secret of sincerity, which leads to a meaningful power worth one thousand one hundred and eleven (1111), as a result of the work of four people" (Nursi, 2014a:308).

Through the practices of tarekat such as dhikrullah, etc., it will shape the human identity to become Insan Al-Kamil (complete human being). The impact will always find inner comfort and peace. Said Nursi still considers tarekat practice to be very relevant and effective in shaping the 
personality of the kamil, such as through the behavior of surrendering one's heart (tawajjuh) to Allah, especially when doing worship to improve the standard of life of syari'at.

Said Nursi raises four steps in achieving Allah's Oneness to achieve human beings easily for ordinary people to do it because it prioritizes the essence of sharia (haqiqah syar'iyyah) than the essence of Sufism. The first is through the way of feeling weak (al-'ajz); this feeling will shape the individual character for longing for Allah SWT, manifested by the manifestation of Allah's attributes within. The second is through a sense of al-faqr. This feeling is manifested in the form of a feeling of dependence solely on the nature of $A r$ Rahman towards Allah (Abdulkarim, K.A., \& Suud, F.M. 2020). The third is through the sense of al-syafaqah (love and compassion). This feeling will shape the individual character (Khaidir et al., 2020) towards the straight path according to Allah's pleasure; this feeling will also lead a person to the nature of Allah in the form of Ar-Rahim. The fourth is through the way of tadhabbur by using the approach of the inner eye (heart) every time you get closer to Allah. The fifth is through the al-tafakkur path, which is to use the mind every time you perform worship through maximizing the gratitude of the blessings that Allah SWT has given.

\section{Conclusion}

The self-actualization of Bediuzzaman Said Nursi in the Risālah Al-Nūr book is part of the inner experience (journey) that cannot be separated from the concept of "self" in humans and the needs that must be met. The concept of "self" is found in humans, including material (consisting of elements of physical power, nafsani power, and tafakkur power) and non-material (consisting of the elements of rabbani power, spiritual power, and tadhabbur power). The human "self" forces have a close correlation with the fulfillment of needs that are conceptually different from the humanistic figure, Abraham Maslow, in the aspect of spirituality. Said Nursi divides human needs into two aspects: first, mundane aspects consist of nafsani needs (essential and metaphorical), a sense of qona'ah, a sense of wara', and a sense of brotherhood between people. The second is the ukhrawi aspect, consisting of a sense of faith, tawakkal, tafakkur based on tauhid, feeling of Ihsan, and a sense of divine love.

Bediuzzaman Said Nursi places "spirituality" as the ultimate need, becoming a role model as a differentiator from other figures. Spiritual is knowing the oneness of insight about Allah SWT (ma'rifatullah) through the subconscious spiritual senses' inner eye, which is activated through tafakkur and tadabbur power. The spiritual journey of Said Nursi is divided into two, namely: first, spiritual disgrace (the lowest). This kind of experience is experienced by individuals dominated by the nafsani drive because it leads to the world worship process, even negligence towards the behavior of ahsanu taqwim (best form). Spiritual reproach is owned by the heretics "adhõllîn"; people who slip into naturalism and adherents of naturalist thought. The second is praiseworthy (the holiest) spirituality. This spiritual experience has a straight, luminous path for those who cling to the Qur'an (alladinah an'amta 'alaihim) so that they can actualize themselves as "Caliph of Allah" and "Servant of Allah", who will then receive the title of a perfect human (Insan Kamil).

Conceptually, in Islamic Education Psychology, the discussion of humans' "self" is almost the same as the concept offered by Said Nursi. Both make the Qur'an a masterpiece in thinking. It is just that there are several terms used. Selfactualization in Said Nursi has implications for the paradigm building of Islamic Education Psychology. In detail, there are several implications of Badiuzzaman Said Nursi's selfactualization on the development of Islamic Psychology Education (Suud et al., 2020). The first is the implication at the philosophical level. The understanding of the essence of selfactualization is to maximize the potential of the individual soul in knowing in the context of human development to the level of Insan AlKamil. The second is the implication at the material level. Said Nursi is very keen to fight for the ideas of tauhid and dhikurullah. The essence of tauhid is basically a manifestation (tajalli), which is none other than the reflection of Allah's 
attributes and His Caliph on earth. The third is the implication at the methodological level. The methods offered by Said Nursi are the selfactualization method through Munazârât (Debate/Discussion), the self-actualization method through Mudhadharah (lectures), the selfactualization method through Qisah (stories), the self-actualization method through Mukâtabah (Making letter/writing), self-actualization method through Tausiyah (Giving advice), selfactualization method through Maudu'i (Making themes), and self-actualization method through Uswah (Giving an example).

\section{References}

1. Abdulkarim, K.A., \& Suud, F.M. (2020). Evaluation of Madaris Curriculum Integration for Primary Muslim Education in Mindanao: An Assessment of The Influence of Psychology. International Journal of Islamic Educational Psychology, 1(2), 89-100. DOI: https://doi.org/10.18196/ijiep.v1i2.9736

2. Ahmad Junaidi. (2016, November). Kebijakan Politik Recep Tayyib Erdogan dan Islamisme Turki Kontemporer | Junaidi | IN RIGHT: Jurnal Agama dan Hak Azazi Manusia. Retrieved June 19, 2020, from In Rigt Jurnal website: http://ejournal.uin-

suka.ac.id/syariah/inright/article/view/144 4

3. Al-Faruqi, I. R. (1980). Sources of Islamic Thought: Three Epistles on Tawhid by Muhammad ibn 'Abd al Wahhab, tr. and ed. Indianapolis: American Trust Publications.

4. Alexander, F. (1935). The Psychoanalysis of the Total Personality: The Application of Freud's theory of the ego to the neuroses, The psychoanalysis of the total personality: The application of Freud's theory of the ego to the neuroses. Retrieved from https://doi.org/10.1037/11565-000.

5. Boer., T. J. de. (1903). The History of Philosophy in Isläm. Translated by E. R. Jonas, $\quad$ B.D. $\quad$ pp. 216. https://doi.org/https://doi.org/10.1017/S00 35869X00031798
6. Fios, F. (2019). Menjadi Manusia Spiritual-Ekologis Di Tengah Krisis Lingkungan - Sebuah Review. Jurnal Sosial Humaniora, 12(1), 39. https://doi.org/10.12962/j24433527.v12i1. 5066

7. Frager, R. (2005). Hati, Diri, dan Jiwa: Psikologi Sufi untuk Transformasi, terj. Hasmiyah Rauf. Jakarta: Serambi.

8. Hamsah, U. (2019). Müsbet Hareket Dalam Relasi Antar Agama Ditinjau Dari Perspektif Teori Hirarkhi Kebutuhan Abraham Maslow. RELIGI JURNAL STUDI AGAMA-AGAMA, 14(2), 268. https://doi.org/10.14421/rejusta.2018.1402 $-06$

9. Ihsan Kasim Salih. (2003). Said Nursi Pemikir dan Sufi Besar Abad 20; Membebaskan Agama dari Dogmatisme dan Sekularisme. Penerjemah: Nabilah Lubis. Jakarta: Murai Kencana.

10. Keshavarz, S. (2012). Philosophy of Education in Exceptional Children According to Islam. Procedia - Social and Behavioral Sciences, 46, 2917-2921. https://doi.org/10.1016/j.sbspro.2012.05.5 89

11. Khitam, H. (2016). Kontekstualisasi Teologi sebagai Basis Gerakan Ekologi. DINIKA: Academic Journal of Islamic Studies, $\quad 1(2), \quad 143$. https://doi.org/10.22515/dinika.v1i2.62

12. Khaidir, E., \& Suud, F. M. (2020). Islamic Education in Forming Students' characters at As-Shofa Islamic High School, Pekanbaru Riau. International Journal of Islamic Educational Psychology, 1(1), 5063. 10.18196/ijiep.1105

13. Masyhuri, S., Azhar, M., \& Suud, F. M. (2020). The Concept of Happiness For Islamic Community of Melayu Kampar Riau Indonesia. Journal of Critical Reviews, 7(12), 833-838.

14. Minhaji, A. (2009). Strategies For Social Reseach; The Methodological Imagination In Islamic Studies (Bahan Kuliah untuk Metodologi Penelitian dalam Bidang Studi Islam). Yogyakarta: SUKA Press.

15. Nursi, B. S. (2000). The Flashes Collection. Trans. Şükran Vahide. 
Angkara: Sozler Nesriyat ve Sanayi A.S.

16. (2003a). Dari Cermin Keesaan

Allah. Penerjemah: Sugeng Hariyanto. Jakarta: Prenada Media Groups.

17. (2003b). Risālah Al-Nūr: Menikmati takdir Langit. Penerjemah: Sugeng Haryanto, Mohammad Rudi Atmoko dan Umi Rohimah. Jakarta: Raja Grafindo Persada.

18. . (2003c). The Rays Collection.

Trans. Şükran Vahide. Istanbul: MAK Ofset Basm Yayn Tic. ve San. Ltd. fiti.

19. (2008). The Words: On the Nature and Purposes of Man, Life, and All Things. Trans. Sükran Vahide. Istanbul: MAK Ofset Basm Yayn Tic. ve San. Ltd. fiti.

20. (2011). Al-Kalimat; Seputar

Tujuan Manua, Aqidah, Ibadah dan Kemukjizatan Al-Qur'ān. Jakarta: Prenada Media.

21. . (2013). Signs of Miraculousness The Inimitability of The Qur'an's Conciseness. Trans. Şükran Vahide. Angkara: Sözler Neşriyat A. Ş.

22. (2014a). Al-Lama'at; Membumikan Inspirasi Ilahi. Penerjemah: Fauzy Bahreisy and Joko Prayitno. Jakarta: Risālah Nūr Press.

23. (2014b). Al-Lama'at; Membumikan Inspirasi Ilahi. Penerjemah: Fauzy Bahreisy dan Joko Prayitno. Jakarta: Risālah Nūr Press.

24. . (2014c). Al-Mastnawi An-Nuri; Menyibak Misteri Keesaan Ilahi. Penerjemah Fauzi Bariesy. Jakarta: Anatolia.

25. . (2014d). Letters. Trans. Şükran Vahide and others. Istanbul: Sözler Publications A.Ş.

26. Nursi, B. S. (2016). Risalah Ana \& Thabiat. Penerjemah: Fauzi Faishal Bahrieisy. Jakarta: Risālah Nūr Press.

27. (2017a). Al-Maktubât. Penerjemah: Fauzi Faisal Bahreisy. Jakarta: Risālah Nūr Press.

28.__ S. (2017b). Iman Kunci Kesempurnaan. Penerjemah: Fauzi Faisal Bahreisy. Jakarta: Risālah Nūr Press.

29. Raharjo, D. M. (1997). Insan Kamil;
Konsepsi Manusia menurut Islam. Jakarta: Grafiti Press.

30. Rahmatullah, A.S., \& Azhar, M. (2020). Solving Juvenile Delinquency with Death Education Model. International Journal of Islamic Educational Psychology, 1(2), 147-161.

DOI: https://doi.org/10.18196/ijiep.v1i2.9705

31. Ricoeur, P. (1970). Freud and Philosophy: A.n Essay on Interpretation (12th ed.). https://doi.org/10.5840/ipq197212123

32. _ (1996). Onself as Another. Chicago: The University of Chicago.

33. (2005). The Course of Recognition. https://doi.org/10.7227/r.11.1.13

34. Saifuddin, A. F. (2005). Antropologi Kontemporer Suatu Pengantar Kritis Mengenai Paradigma. Jakarta: Prenada Media.

35. Salim, E. (2010). Ratusan Bangsa Merusak Satu Bumi. Jakarta: PT. Kompas Media Nusantara.

36. Sultoni, A., Wasim, A. T., \& Fauzan, A. (2020). Development of Prophetic Intelligence (Phenomenology Study of Religious Transformation). International Journal of Islamic Educational Psychology, 1(1), 10.18196/ijiep.1102

12-24.

37. Suud, F. M., Rahmi, A., \& Fadhilah, F. (2020). Ayah dan Pendidikan Karakter Anak (Kajian Teks dan Konteks Perspektif Psikologi Pendidikan Islam). $A L$ MURABBI: Jurnal Studi Kependidikan dan Keislaman, 7(1), 1-14.

38. Suud, F. M., Chaer, M. T., \& Setiawan, W. (2020). Implementation Educational Psychology Theories at Traditional Boarding School in Aceh. Journal of Critical Reviews, 7(9), 371-377.

39. Wahyuna, A. H., \& Fitriana, S. (2020). The Concept of Hope in The Western and Eastern Perspective. International Journal of Islamic Educational Psychology, 1(1), 25-36. 10.18196/ijiep.1103

40. Zainuddin, M. (2013). Teologi Bencana Dalam Al-Qur'an. Unisia, 35(78), 45-60. https://doi.org/10.20885/unisia.vol35.iss 7 8.art5 